\title{
Decreased Neuroendocrine Responses to Meta- Chlorophenylpiperazine (m-CPP) but Normal Responses to Ipsapirone in Marathon Runners
}

\author{
Andreas Broocks, M.D., Tim Meyer, M.D., Annette George, M.D., Ursula Hillmer-Vogel, M.D., \\ Detlef Meyer, M.D., Borwin Bandelow, M.D., Göran Hajak, M.D., Uwe Bartmann, Ph.D., \\ Christoph H. Gleiter, M.D., and Eckart Rüther, M.D.
}

Several clinical studies suggest antidepressive and anxiolytic effects of regular aerobic exercise. To study the effects of exercise on central serotonergic receptor sensitivity, we performed neuroendocrine challenges using oral doses of meta-chlorophenylpiperazine ( $m$-CPP, $0.4 \mathrm{mg} /$ $\mathrm{kg})$, ipsapirone $(0.3 \mathrm{mg} / \mathrm{kg})$ and placebo in 12 marathon runners and 12 healthy controls not practicing regular exercise. After administration of the nonselective serotonergic agonist $m-C P P$, which exerts a number of wellreproducible effects mainly by means of its action on $5-\mathrm{HT}_{2 \mathrm{C}}$ receptors, marathon runners showed a significantly reduced cortisol response in comparison to the control group. There was also a statistical trend toward a blunted prolactin response after $m-C P P$ in the athlete group. In contrast, the increase of cortisol and the hypothermia observed after administration of the $5-H T_{1 A}$ agonist ipsapirone were of the same magnitude in both groups. The behavioral response to $m-C P P$ or ipsapirone and the mean maximal increases of plasma adrenaline and noradrenaline did not differ between the marathon and the control group. In conclusion, exercise-induced downregulation of $5-\mathrm{HT}_{2 \mathrm{C}}$ receptors could play an important role in mediating the anxiolytic and antidepressive effects of exercise.

[Neuropsychopharmacology 20:150-161, 1999] (C) 1998 American College of Neuropsychopharmacology. Published by Elsevier Science Inc.
KEY WORDS: Exercise; Marathon running; Serotonin; Meta-chlorophenylpiperazine (m-CPP); Ipsapirone

Several studies of healthy volunteers have shown a positive effect of endurance training on anxiety, depressive symptoms, self-esteem, concentration, sexual satisfaction, and stress tolerance (de Coverley Veale 1987; Farmer et al.

From the Department of Psychiatry, University of Göttingen, Göttingen, Germany (AB, DM, BB, GH, UB, ER), the Department of Neurology (AG), University of Würzburg, Würzburg, Germany; the Department of Clinical Pharmacology (CHG), Department of Sports Medicine (UH-V), University of Göttingen, Göttingen, Germany; Institute of Sports and Preventive Medicine (TM), University of Saarbrücken, Saarbrücken, Germany.

Address correspondence to: Dr. A. Broocks, The Department of Psychiatry, University of Göttingen, von-Siebold-Strasse 5, D-37075 Göttingen, Germany.

Received 28 October 1997; revised 12 March 1998; accepted 13 April 1998.
1988; Hughes 1984; Lennox et al. 1990; MacMahon 1990; Sothman et al. 1992). There is also some evidence that exercise is effective against mild-to-moderate depression and against anxiety disorders (Doyne et al. 1987; Greist et al. 1979; Martinsen et al. 1985; McCann and Holmes 1984; Pappas et al. 1990; Sexton et al. 1989). Research in sports medicine has focused on physiological and immunological consequences of exercise, and little is known about changes in central neurotransmitter function associated with acute or regular endurance training.

Several lines of evidence suggest that motor activity affects central serotonin metabolism. In the cerebrospinal fluid of depressed patients, the concentration of the serotonin metabolite 5-HIAA was significantly higher after 4 hours of motor activity than in the same patients after bed rest (Post et al. 1973). Aerobic exercise causes a rise of free fatty acids (Davis et al. 1992; Fischer et al. 
1991), which displace free tryptophan (TRP) from its plasma-protein-binding sites (Blomstrand et al. 1988; Chaouloff et al. 1986). This leads to an increase of free TRP in relation to other large neutral amino acids (LNAA) (Chaouloff et al. 1989). Because the TRP influx into the brain correlates with the TRP/LNAA plasma ratio (Fernstrom and Wurtman 1971; Wurtman and Fernstrom 1976), exercise leads to a higher precursor availability in the brain, which, in turn, stimulates 5-HT synthesis (Broocks et al. 1989; Chaouloff 1997). Data from animal studies show that hyperactivity is also associated with an increased turnover of serotonin in the mediobasal hypothalamus (Broocks et al. 1991). On the basis of these findings, we have hypothesized that repeated stimulation of central serotonin turnover by exercise could lead to an adaptive downregulation of $5-\mathrm{HT}_{2 \mathrm{C}}$ receptors. Clinical studies in patients with obsessive-compulsive disorder (OCD) have shown that chronic administration of clomipramine was associated with a significantly diminished behavioral and hyperthermic response to $\mathrm{m}-\mathrm{CPP}$, although the same dose of $\mathrm{m}$-CPP had led to significantly higher plasma concentrations of m-CPP (Zohar et al. 1988). Accordingly, reduced behavioral sensitivity to m-CPP was also observed after chronic administration of fluoxetine to OCD patients (Hollander et al. 1992). Following 3 weeks of paroxetine treatment, both the prolactin and hyperthermic responses to $\mathrm{m}$-CPP were significantly attenuated in seven healthy volunteers (Quested et al. 1997).

During the last decade, $\mathrm{m}$-CPP has been used frequently to probe human serotonergic function (Kahn and Wetzler 1991; Murphy et al. 1996; Murphy et al. 1991). Generally, it has been found to elicit neuroendocrine responses (e.g., elevations in plasma cortisol, ACTH, and prolactin), physiological effects (e.g., increases in blood pressure and temperature), and behavioral effects, which showed a characteristic pattern depending upon the neuropsychiatric disorder studied (Brewerton et al. 1992; Kahn and Wetzler 1991; Murphy et al. 1996; Murphy et al. 1991). Based on studies of second messenger system effects, antagonist profiles, and cross-tolerance investigations with $5-\mathrm{HT}_{1 \mathrm{~A}}, 5-\mathrm{HT}_{2 \mathrm{~A}}$, and $5-\mathrm{HT}_{2 \mathrm{C}}$ agonists, the effects of $\mathrm{m}-\mathrm{CPP}$ on prolactin, $\mathrm{CRH} / \mathrm{ACTH} /$ cortisol, body temperature, as well as anorectic, anxiogenic, and other behavioral responses have most commonly been attributed to actions mediated by $5-\mathrm{HT}_{2 \mathrm{C}}$ receptors, where $\mathrm{m}-\mathrm{CPP}$ acts as a partial agonist (Aulakh et al. 1992; Calogero et al. 1993; Kennett et al. 1989; Mazzola-Pomietto et al. 1995).

Ipsapirone has shown anxiolytic effects in animal anxiety models (De Vry et al. 1991). It has been investigated in single-dose challenge paradigms to assess the physiological functions mediated by $5-\mathrm{HT}_{1 \mathrm{~A}}$ receptors in humans, and to evaluate whether the functional responsivity of the 5- $\mathrm{HT}_{1 \mathrm{~A}}$ receptor complex might be altered in patients with neuropsychiatric disorders and following treatment of these disorders. The $5-\mathrm{HT}_{1 \mathrm{~A}}$ binding sites are predominantly located on serotonergic neurons in the raphe nuclei (presynaptic autoreceptors) and in limbic structures (postsynaptic receptors). Agonistic properties at presynaptic somatodendritic sites have been observed, resulting in decreased serotonergic neurotransmission (Peroutka 1985). At postsynaptic sites, ipsapirone acts as a partial agonist. Ipsapirone, given in doses of $0.1,0.2$, and $0.3 \mathrm{mg} / \mathrm{kg}$ to male volunteers, produced dose-dependent, statistically significant increases in plasma cortisol and ACTH at the two higher ipsapirone doses (Kahn et al. 1994; Lesch et al. 1989). Ipsapirone also induced dose-dependent reductions in body temperature without any effects on blood pressure, heart rate, or respiratory rate (Lesch et al. 1990; Lesch et al. 1989). Animal research has shown that acute or chronic motor activity does not affect $5-\mathrm{HT}_{1 \mathrm{~A}}$ receptor associated behavior in rats (Chaouloff 1994).

In the present study, we performed neuroendocrine challenges using $\mathrm{m}-\mathrm{CPP}$, ipsapirone, and placebo in marathon runners and healthy untrained controls to compare 5- $\mathrm{HT}_{2 \mathrm{C}}$ and 5- $\mathrm{HT}_{1 \mathrm{~A}}$-specific psychobehavioral and neuroendocrine response patterns. The fitness level of all subjects was verified by bicycle spiroergometry.

\section{METHOD}

\section{Study Design}

To compare the psychobehavioral and neuroendocrine effects of orally administered $\mathrm{m}-\mathrm{CPP}(0.4 \mathrm{mg} / \mathrm{kg})$, ipsapirone $(0.3 \mathrm{mg} / \mathrm{kg})$, and placebo, marathon runners and healthy volunteers participated in three challenge sessions, conducted in a randomized double-blind fashion on separate days.

\section{Subjects}

Twelve marathon runners and 12 healthy controls of comparable age and sex distribution were recruited by newspaper advertisements. The marathon runners were required to cover a weekly running distance of at least $60 \mathrm{~km}$ per week and to have practiced regular training habits for at least 2 years prior to the study. The inclusion criterion for the control subjects was abstinence from regular aerobic exercise for at least 2 years prior to the study. All subjects received financial compensation for their participation. The Structured Clinical Interview for DSM-III-R (SKID) revealed no evidence of a psychiatric disorder for any subject. None of the volunteers had a history of significant medical disorders, and all volunteers had a normal physical examination, electrocardiogram, and routine laboratory tests prior to inclusion in the study. All volunteers had to be drug-free for at least 3 weeks prior to and during testing. This was verified by urinary drug screening prior 
to the first challenge. After the entire procedure had been explained, all participants gave written, informed consent. The trial was approved by the Ethics Committee of the Medical Faculty of the University of Göttingen. The marathon and the control group did not significantly differ from each other with respect to age (33.9 \pm 6.7 vs. $33.45 \pm 5.4$ years), sex distribution (male/female: $9 / 3$ vs. $6 / 6)$, weight $(69.5 \pm 10.8$ vs. $70.7 \pm 10.3 \mathrm{~kg})$, and height $(176.0 \pm 6.9$ vs. $174.2 \pm 7.3 \mathrm{~cm})$.

\section{Challenge Procedures}

There was an interval of at least 48 hours between two challenges. On the day of each challenge session, subjects arrived at the sleep laboratory of the Department of Psychiatry (University of Göttingen) at approximately 12:30 for a standardized meal. During the challenge sessions, subjects abstained from eating or sleeping and remained supine with the head elevated. The timing of recumbancy was equal for all subjects. At 13:00, an intravenous catheter was placed in an antecubital vein for repeated blood sampling. At 14:30, 2 to 4 capsules of either m-CPP $(0.4 \mathrm{mg} / \mathrm{kg})$, ipsapirone $(0.3$ $\mathrm{mg} / \mathrm{kg}$ ), or placebo were administered orally.

Behavioral effects were assessed using the Acute Panic Inventory (Dillon et al. 1987) and a modified version of the NIMH Self-Rating Scale (Murphy et al. 1989) that comprises 24 questions and defines six subscales of behavioral change: anxiety, activation-euphoria, altered self-reality, depressive affect, dysphoria, and functional deficit. Behavioral ratings were completed at 14:00, 14:30, 15:00, 15:30, 16:00, 16:30, 17:30, and 18:30. A summary measure of behavioral change (designated "total score on the NIMH scale"), defined by the combined scores for the anxiety, activation-euphoria, dysphoria, altered self-reality, depression, and functional deficit subscales, was included in the analysis to assess the over-all effect of each drug challenge on behavior.

Baseline blood samples were drawn at 14:00 and at 14:30 (immediately prior to medication intake), and serial blood draws were subsequently made at 15:00, 15:30, 16:00, 16:30, 17:30, and 18:30. Samples were immediately placed on ice, centrifuged within $15 \mathrm{~min}$ of collection, and the plasma was stored at $-70^{\circ} \mathrm{C}$ until assay. Plasma samples were assayed for prolactin, cortisol, noradrenaline (NE), adrenaline, and plasma concentrations of $\mathrm{m}-\mathrm{CPP}$ and ipsapirone. Throughout each challenge session, oral temperature as well as blood pressure and heart rate were measured at 30-min intervals.

Plasma concentrations of $\mathrm{m}-\mathrm{CPP}$ were measured by high-performance liquid chromatography (HPLC) using a method described by Murphy and co-workers (Murphy et al. 1989). Ipsapirone was measured by HPLC and UV detection. Prolactin and cortisol were determined by enzyme-linked immunoassay (ELISA) (Immundiagnostica Enzyme Test ${ }^{\mathrm{TM}}$ Cortisol, No 1288946, and Prolactin, No 1448609. Boehringer-Mannheim); the interassay variability was 6.5 to $7.5 \%$ for prolactin and 6.2 to $7.9 \%$ for cortisol. NE and adrenaline were measured by HPLC as previously described (Pirke et al. 1985); the average interassay variability was $6.2 \%$ for NE and $8.4 \%$ for adrenaline. Urine samples were screened for benzodiazepines by EMIT.

\section{Bicycle Spiroergometry}

An incremental bicycle spiroergometry was performed by all subjects on a Bosch ERG 551 bicycle ergometer. Their workload was increased every 3 min until subjective exhaustion. The starting load ranged between 50 and 100 watts, depending upon body weight, sex, and age; that is, subjects with lower body weight (which usually means lower leg muscle strength) and higher age were started with 50 watts only. The increment was 25 or 50 watts according to the criteria mentioned. Capillary blood samples were taken from the right earlobe in the resting state and during the last $10 \mathrm{~s}$ of each stage. Exspiratory air was collected using a standardized Douglas-bag sampling method during the last min of each working stage. Lactate measurements were done enzyme-photometrically. Peak power output $\left(\mathrm{P}_{\max }\right)$, physical work capacity at a heart rate of $150 / \mathrm{min}$ (PWC $150)$, and maximal oxygen consumption $\left(\mathrm{V}_{\mathrm{O} 2 \mathrm{max}}\right)$, heart rate (HR), vital capacity (VC), and maximal heart rate $\left(\mathrm{HR}_{\max }\right)$ were determined using standard procedures. For each stage, subjects were asked to rate the degree of their perceived exertion (RPE) by means of the Borg Scale (Borg and Noble 1974). A physician was present during the entire procedure. There was a minimum of at least 48 hours between spiroergometry and a neuroendocrine challenge.

\section{Data Analysis}

The maximal increase of all parameters (maximal decrease for temperature) were used as the primary response criteria. It was calculated individually using the greatest positive difference between the baseline value and each of the following six time points. The maximal increase of psychobehavioral and hormonal parameters following the administration of $\mathrm{m}-\mathrm{CPP}$, ipsapirone or placebo was calculated and compared with the Wilcoxon-Mann-Whitney U-test between marathon athletes and controls. For temperature changes after administration of ipsapirone, maximal decreases of temperature were used. In addition, data were also examined using a three-factor repeated measures analysis of variance model (ANOVA). The first repeated factor, drug challenge, was defined by two pharmacological challenges given to subjects on different days: m-CPP/ placebo or ipsapirone/placebo. The second repeated factor, time, was defined by baseline followed by six 
postbaseline time points. These time points were selected on the basis of findings from earlier studies in which m-CPP was administered orally (Murphy et al. 1989). The third factor, group, was defined by the marathon and the control group. A conventional univariate repeated measures approach was taken to investigate the main effects of drug challenge, time, group and the following interactions: drug challenge $\times$ time, drug challenge $\times$ group, and drug challenge $\times$ time $\times$ group.

Post hoc analyses were only performed in the case of significant main effects of drug challenge, group, and the interactions mentioned above. If the main effect of drug challenge or the interaction of drug challenge and time were significant, further analysis was done comparing changes from baseline after drug intake with those after placebo for each time point separately. If the main effect of group or the interaction of group and drug challenge was significant, further analysis was done comparing changes from baseline after drug intake in marathon runners with those in controls for each time point separately. A $p$-value of less than 0.05 was interpreted as significant for the main effects and all further analysis. Regarding the main effects and the interaction, $p$-values were adjusted using the Greenhouse-Geisser correction (Greenhouse and Geisser 1959) provided that the responding epsilon was less than 1.
The baseline values for all psychobehavioral and neuroendocrine data on the 3 challenge days were used to calculate a mean baseline value for every subject. In a second step, these means were used to compare baseline variables in the athlete and the control group by exact Wilcoxon analysis; $p$-values were adjusted by the Bonferroni-Holm method. Comparisons for the spiroergometric data were performed by the exact version of the Wilcoxon-Mann-Whitney U-test. Categorial data were compared with Fisher's Exact Test. Two-tailed tests were used throughout. All statistical analyses were done using SAS 6.11 software (SAS 1989).

\section{RESULTS}

\section{Spiroergometry}

Table 1 shows the results from spiroergometric testing in the athlete and the control group. As expected, there were highly significant differences in all measures of aerobic fitness when marathon runners were compared to untrained controls. There were no statistical differences between the two groups as regards vital capacity, maximal heart rate, respiratory exchange ratio (at baseline and at maximum power output), and self-rated perceived exertion.

Table 1. Measures of Spiroergometric Performance in Marathon Runners and Untrained Healthy Controls

\begin{tabular}{|c|c|c|c|}
\hline & $\begin{array}{l}\text { Marathon } \\
\text { Runners } \\
(n=12)\end{array}$ & $\begin{array}{l}\text { Control } \\
\text { Subjects } \\
(n=12)\end{array}$ & $p$-value \\
\hline \multicolumn{4}{|l|}{$\mathrm{V}_{\mathrm{O} 2 \max }$} \\
\hline $\begin{array}{l}(\mathrm{ml} \text { per } \min \times \mathrm{kg} \text { body weight }) \\
\mathrm{P}_{\max } / \mathrm{kg}\end{array}$ & $55.6 \pm 8.2$ & $36.2 \pm 6.7$ & $<.001$ \\
\hline (watts per kg body weight) & $4.71 \pm 0.69$ & $2.79 \pm 0.56$ & $<.001$ \\
\hline $\begin{array}{l}\mathrm{PWC}_{150} / \mathrm{kg} \\
\quad \text { (watts at heart rate } 150 / \mathrm{min} . / \mathrm{kg} \text { ) }\end{array}$ & $2.95 \pm 0.55$ & $1.65 \pm 0.53$ & $<.001$ \\
\hline $\begin{array}{l}\mathrm{P}_{\text {Lac } 4 / \mathrm{kg}} \\
\quad \text { (watts at } 4 \mathrm{mmol} \text { lactate } / \mathrm{kg} \text { ) }\end{array}$ & $3.27 \pm 0.52$ & $2.01 \pm 0.47$ & $<.001$ \\
\hline $\begin{array}{l}\mathrm{VC} \\
\text { (liters) }\end{array}$ & $5.22 \pm 0.21$ & $4.7 \pm 0.67$ & ns \\
\hline $\begin{array}{l}\mathrm{HR}_{\text {max }} \\
\quad \text { (heart rate per minute) }\end{array}$ & $186.2 \pm 13.1$ & $185.8 \pm 9.8$ & ns \\
\hline $\begin{array}{l}\text { RER }_{\text {baseline }} \\
\text { (respiratory exchange ratio) }\end{array}$ & $0.81 \pm 0.07$ & $0.87 \pm 0.01$ & ns \\
\hline $\begin{array}{l}\mathrm{RER}_{\max } \\
\text { (max. respiratory exchange ratio) }\end{array}$ & $1.08 \pm 0.04$ & $1.08 \pm 0.06$ & ns \\
\hline $\begin{array}{l}\mathrm{Lac}_{\max } \\
\quad(\mathrm{mmol} / \mathrm{l})\end{array}$ & $12.4 \pm 2.1$ & $9.59 \pm 2.6$ & $<.012$ \\
\hline $\begin{array}{l}\mathrm{RPE}_{\text {max }} \\
\quad \text { (perceived exertion) }\end{array}$ & $19.0 \pm 1.9$ & $18.9 \pm 1.7$ & ns \\
\hline
\end{tabular}

Data (mean $\pm \mathrm{SD}$ ) were compared by exact Wilcoxon analysis (two-tailed test). 
Table 2. Baseline Psychobehavioral and Neuroendocrine Variables in Marathon Runners $(n=12)$ and Healthy Controls $(n=12)$

\begin{tabular}{lccc}
\hline & $\begin{array}{c}\text { Marathon } \\
\text { Runners } \\
\text { (mean, SD) }\end{array}$ & $\begin{array}{c}\text { Control } \\
\text { Subjects } \\
\text { (mean, SD) }\end{array}$ & $\boldsymbol{p}$ value \\
\hline Acute panic inventory (Score) & $0.25(20)$ & $0.14(0.2)$ & $\mathrm{ns}$ \\
NIMH scale (Score) & $0.28(0.40)$ & $0.03(0.1)$ & .088 \\
$\quad$ Activation & $0.08(0.21)$ & $0.05(0.2)$ & $\mathrm{ns}$ \\
Altered self-reality & $0.11(0.03)$ & $0.15(0.4)$ & $\mathrm{ns}$ \\
Anxiety & $0.03(0.09)$ & $0.01(0.1)$ & $\mathrm{ns}$ \\
Depression & $0.06(0.12)$ & $0.08(0.2)$ & $\mathrm{ns}$ \\
Dysphoria & $0.19(0.30)$ & $0.05(0.2)$ & $\mathrm{ns}$ \\
Functional deficit & $7.67(2.11)$ & $8.71(4.7)$ & .01 \\
Hormones & $116.3(46.8)$ & $206.8(83.5)$ & $\mathrm{ns}$ \\
Cortisol $(\mu \mathrm{g} / \mathrm{dl})$ & $216.25(70.49)$ & $218.9(84.0)$ & .071 \\
Prolactin $(\mu \mathrm{U} / \mathrm{ml})$ & $32.73(23.5)$ & $27.5(14.7)$ & .054 \\
$\quad$ NA $(\mathrm{ng} / \mathrm{l})$ & $36.52(0.27)$ & $36.73(0.27)$ & \\
Adrenaline $(\mathrm{ng} / \mathrm{l})$ & & & \\
Temperature $\left({ }^{\circ} \mathrm{C}\right)$ & & & \\
\hline
\end{tabular}

Data are given as mean (SD) and were compared by exact Wilcoxon analysis (two-tailed test).

\section{Comparison of Psychobehavioral and Neuroendocrine Variables at Baseline}

Table 2 shows mean baseline values for behavioral, temperature, and hormonal data calculated from the baseline parameters of the three challenge tests. In comparison with controls, the plasma level of prolactin was significantly decreased in marathon runners. There was also a statistical trend toward decreased temperature and an increased activation score at baseline in the marathon group. All other behavioral and neuroendocrine data did not differ between marathon runners and controls at baseline.

\section{Psychobehavioral Response to m-CPP and Ipsapirone}

Figure 1 illustrates the maximum increase in self-rated measures of anxiety (API) and the sum score of the NIMH Rating Scale following the administration of ipsapirone, m-CPP, and placebo. In summary, the behavioral response to ipsapirone and $\mathrm{m}-\mathrm{CPP}$ was not significantly different between marathon runners and controls. After administration of m-CPP, the ANOVA did not reveal any significant main effects for the behavioral ratings as measured by the sum score of the NIMH Rating Scale or the API in marathon athletes or controls. In contrast, after administration of ipsapirone, there were significant effects for drug challenge $(\mathrm{F}=$ $13.31 ; \mathrm{df}=1,21 ; p=.0015)$, time $(\mathrm{F}=11.62 ; \mathrm{df}=6,126$; $p=.0005)$, and the interaction of drug challenge with time $(\mathrm{F}=9.66 ; \mathrm{df}=6,126 ; p=.0015)$. The ANOVA did not reveal any significant main effects for group or for the interactions (drug challenge $\times$ group, and drug challenge $\times$ time $\times$ group).
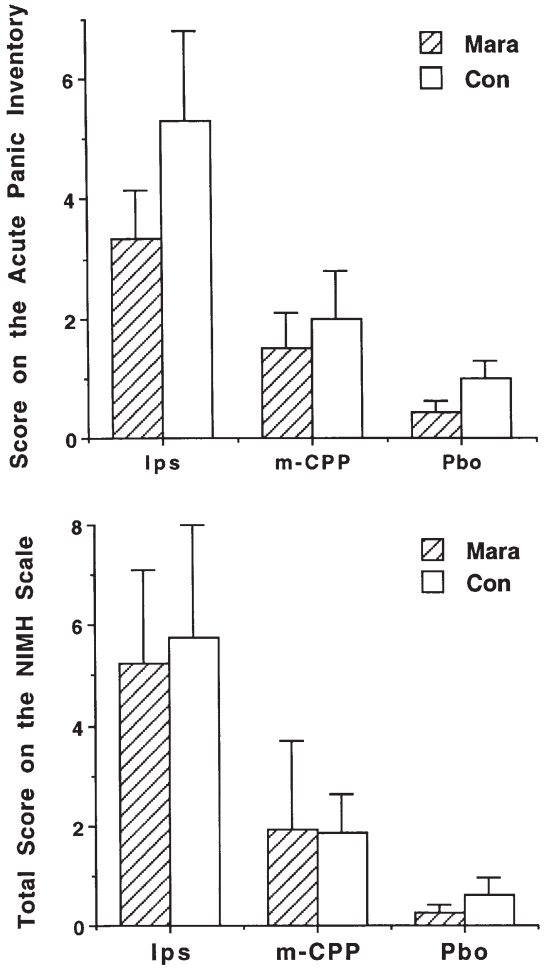

Figure 1. Maximum increase in self-rated measures of anxiety (Acute Panic Inventory) and the sum score of the NIMH Rating Scale in marathon runners (Mara, $n=12$ ) and healthy controls (Con, $n=12$ ) following the administration of ipsapirone, $\mathrm{m}-\mathrm{CPP}$, and placebo. Comparisons between marathon runners and controls were done by with the WilcoxonMann-Whitney test. No significant differences were found between the groups. 


\section{Neuroendocrine and Body Temperature Changes}

The mean maximal changes in hormone concentrations were compared between marathon runners and controls by the exact Wilcoxon-Mann-Whitney U-test. As Figure 2 illustrates, the m-CPP-induced maximal cortisol response was significantly lower in the athlete group as compared to the controls $(p=.006)$. There was also a statistical trend toward a blunted prolactin response in the marathon group $(p=.089)$. All other hormonal responses following $\mathrm{m}-\mathrm{CPP}$, ipsapirone, or placebo were not significantly different between the marathon and the control group.

In Figure 3, the mean changes in plasma concentrations of cortisol between baseline and selected postbaseline time points are compared graphically for drug challenges using m-CPP, ipsapirone, or placebo. After administration of $\mathrm{m}-\mathrm{CPP}$, the ANOVA revealed significant effects for drug challenge $(\mathrm{F}=15.72 ; \mathrm{df}=1,22 ; p=$ $.0007)$, time $(\mathrm{F}=2.9 ; \mathrm{df}=6,132 ; p=.0109)$, and the interaction of drug challenge with time $(\mathrm{F}=5.95$; $\mathrm{df}=$ $6,132 ; p=.0001)$. There was a statistical trend for the interaction of drug challenge and group $(\mathrm{F}=3.07$; $\mathrm{df}=$ $1,22 ; p=.093)$. In controls, plasma cortisol levels were significantly increased $180 \mathrm{~min}$ and $240 \mathrm{~min}$ after administration of $\mathrm{m}-\mathrm{CPP}$. In contrast, no significant in- creases or plasma cortisol levels were observed in the marathon group when the m-CPP challenge was compared to the placebo condition (Figure 3, upper part).

After administration of ipsapirone, the ANOVA revealed significant effects for drug challenge $(\mathrm{F}=31.14$; $\mathrm{df}=1,20 ; p=.0001)$, time $(\mathrm{F}=5.26 ; \mathrm{df}=6,120 ; p=$ $.0109)$ and the interaction of drug challenge with time $(\mathrm{F}=17.29 ; \mathrm{df}=6,120 ; p=.0001)$. The ANOVA did not reveal any significant main effects for group, for the interaction of drug challenge with group $(\mathrm{F}=0.18$; $\mathrm{df}=$ $1,20 ; p .68)$, or for the interaction of drug challenge $\times$ time $\times$ group. In comparison to placebo, plasma cortisol levels were significantly increased 90, 120, 180, and $240 \mathrm{~min}$ after administration of ipsapirone in both the marathon and the control group (Figure 3, lower part).

Figure 4 (upper part) shows the time-course of plasma prolactin following the administration of $\mathrm{m}-\mathrm{CPP}$ and placebo, and the time-course of temperature following the administration of ipsapirone and placebo. After administration of $\mathrm{m}-\mathrm{CPP}$, the ANOVA revealed significant effects for group $(\mathrm{F}=12.06$; $\mathrm{df}=1,21 ; p=$ $.0023)$, drug challenge $(\mathrm{F}=14.56 ; \mathrm{df}=1,21 ; p=.0010)$, time $(\mathrm{F}=17.98 ; \mathrm{df}=6,126 ; p=.0001)$, the interaction of drug challenge with time $(\mathrm{F}=17.20 ; \mathrm{df}=6,126 ; p=$ .0001 ), and the interaction of group, drug challenge,
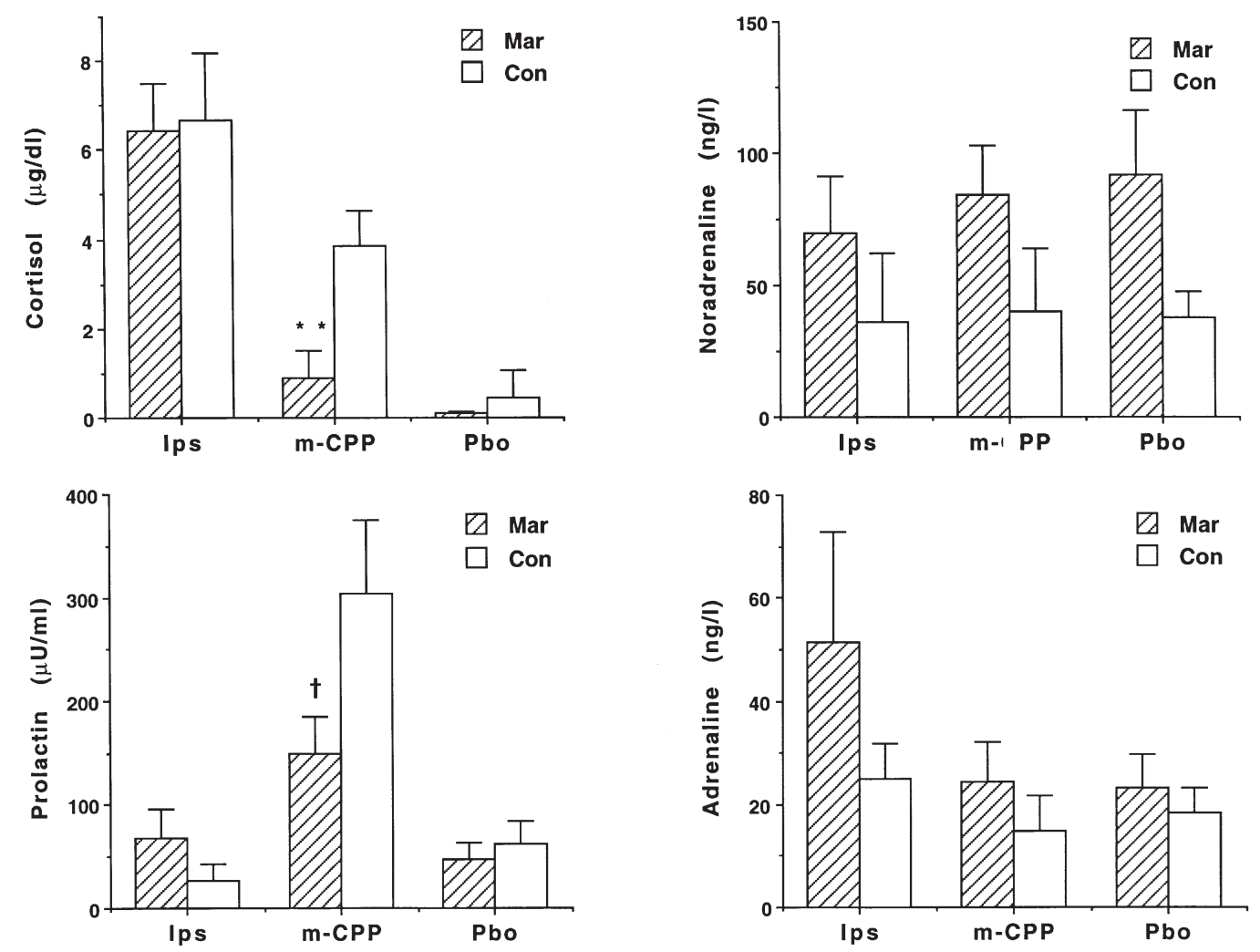

Figure 2. Maximum increase of plasma cortisol, prolactin, norepinephrine, and adrenaline in marathon runners (Mara, $n=$ 12 ) and healthy controls (Con, $n=12$ ) following the administration of ipsapirone, $\mathrm{m}-\mathrm{CPP}$, and placebo. Comparisons between marathon runners and controls were done with the Wilcoxon-Mann-Whitney test. ${ }^{*} p<.05 ;{ }^{* *} p<.01 ;+$ trend $(p=.089)$. 

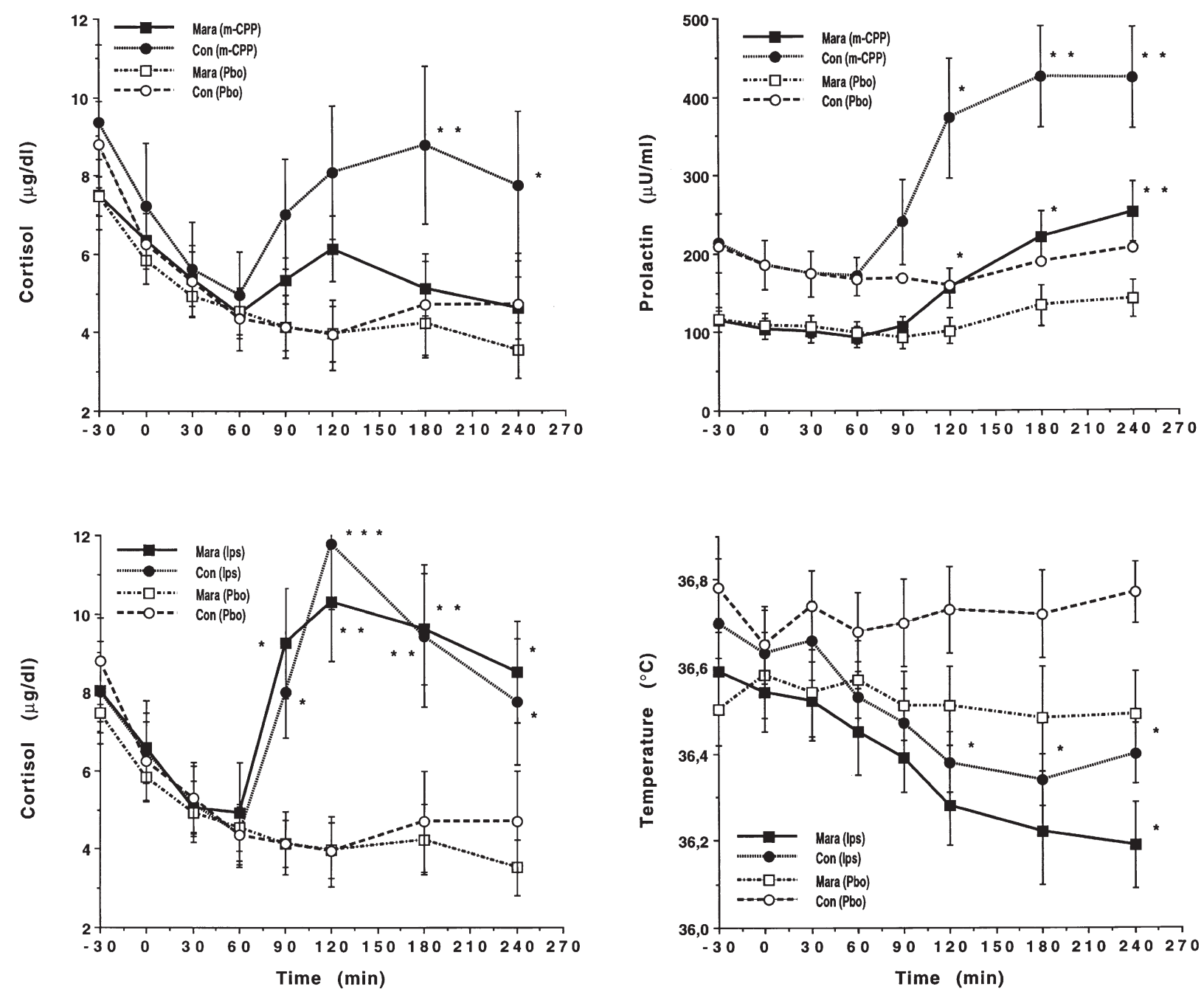

Figure 3. Time course of plasma cortisol in marathon runners (Mara, $n=12$ ) and healthy controls (Con, $n=12$ ) following the administration of $\mathrm{m}-\mathrm{CPP}$ (upper part), ipsapirone (lower part), and placebo (upper and lower part). Drugs were administered at time point $=0 \mathrm{~min}$. Comparisons were done by ANOVA: *ipsapirone or m-CPP vs. placebo, $p<.05$; $\left.{ }^{* *} p<.01 ; * * *<.001\right)$.

and time $(\mathrm{F}=3.7 ; \mathrm{df}=1,26 ; p=.002)$. In comparison to placebo, plasma prolactin levels were significantly increased 120, 180, and 240 min after administration of $\mathrm{m}-\mathrm{CPP}$ in both the marathon and the control group. In addition, prolactin levels were significantly higher in controls at all time points as compared to the marathon group.

Figure 4 (lower part) shows the time-course of temperature following the administration of ipsapirone and placebo. After administration of ipsapirone, the ANOVA revealed significant effects for drug challenge $(\mathrm{F}=27.08 ; \mathrm{df}=1,19 ; p=.0001)$, time $(\mathrm{F}=12.37 ; \mathrm{df}=$ $6,114 ; p=.0001)$, and the interaction of drug challenge

Figure 4. Time course of plasma prolactin following the administration of $\mathrm{m}-\mathrm{CPP}$ and placebo and time course of temperature following the administration of ipsapirone and placebo in marathon runners (Mara, $n=12$ ) healthy controls (Con, $n=12$ ). Drugs were administered at time point $=0$ min. Comparisons were done by ANOVA: *ipsapirone or m-CPP vs. placebo, $\left.p<.05 ;{ }^{* *} p<.01\right)$. Prolactin levels were significantly higher in controls at all time points when compared to the marathon group (not indicated by asterisks).

with time $(\mathrm{F}=6.42 ; \mathrm{df}=6,114 ; p=.0001)$. The ANOVA did not show any significant main effects for group, for the interaction of drug challenge with group, or for the interaction of drug challenge with time and group. In comparison to placebo, temperature was significantly reduced 120, 180, and $240 \mathrm{~min}$ after administration of ipsapirone in the control group; in marathon runners a significant reduction of body temperature was only observed $240 \mathrm{~min}$ after administration of ipsapirone (Figure 4). 


\section{Plasma Concentrations of $\mathrm{m}-\mathrm{CPP}$ and Ipsapirone}

Plasma concentrations of $\mathrm{m}-\mathrm{CPP}$ and ipsapirone were measured across the challenge procedure. Maximum plasma $\mathrm{m}-\mathrm{CPP}$ concentrations were observed $90 \mathrm{~min}$ after administration of the capsule both in marathon runners $(25.54 \pm 22.1 \mathrm{ng} / \mathrm{ml})$ and in controls $(19.3 \pm 11.0$ $\mathrm{ng} / \mathrm{ml}$ ). Ipsapirone reached its maximum plasma concentration $60 \mathrm{~min}$ after drug intake in the marathon group $(27.94 \pm 12.3 \mu \mathrm{g} / \mathrm{l})$ and in the control group $(38.81 \pm 23.7 \mu \mathrm{g} / \mathrm{l})$. ANOVA did not reveal any significant differences in plasma concentrations of $\mathrm{m}$-CPP or ipsapirone between marathon runners and controls.

\section{DISCUSSION}

The major finding of this study is a significantly reduced cortisol response and a blunted prolactin response after administration of $\mathrm{m}-\mathrm{CPP}$ in marathon runners. In contrast, ipsapirone induced a significant increase of cortisol of the same magnitude in both the marathon and the control group. Because other studies using various 5-HT antagonists have consistently shown that the effects of $\mathrm{m}-\mathrm{CPP}$ on prolactin, $\mathrm{CRH}$, $\mathrm{ACTH}$, and cortisol are predominantly mediated by 5- $\mathrm{HT}_{2 \mathrm{C}}$ receptors (Aulakh et al. 1992; Calogero et al. 1993; Mazzola-Pomietto et al. 1995; Murphy et al. 1991; Pigott et al. 1993; Seibyl et al. 1991), our results are in agreement with the hypothesis that regular endurance training leads to a downregulation of central $5-\mathrm{HT}_{2 \mathrm{C}}$ receptors. This conclusion is supported by the attenuated prolactin response in the marathon group, which is also mediated mainly by postsynaptic $5-\mathrm{HT}_{2 \mathrm{C}}$ receptors (Aulakh et al. 1992; Murphy et al. 1991). Ipsapirone induces cortisol secretion via increased ACTH release and not by direct action on the adrenal gland (Przegalinski et al. 1989). The solid cortisol response after administration of ipsapirone in both groups does not support the assumption that the secretion of cortisol in marathon runners is impaired by peripheral adaptations on the pituitary-adrenal level.

The results from the three-factorial ANOVA show that a $0.4 \mathrm{mg} / \mathrm{kg}$ dose of $\mathrm{m}-\mathrm{CPP}$, which is $20 \%$ lower than in most other oral $\mathrm{m}$-CPP studies, still elicits a significant neuroendocrine response as compared to placebo conditions. Analyses that include all time points can mask differences in maximal response that may occur at different time points. This might explain why the interaction of group with drug challenge and time was not significant for cortisol in the three-factorial ANOVA. Nevertheless, our results still must be interpreted with care.

Regular exercise might be associated with adaptive changes on the hypothalamic level. Acute exercise is known to be a strong stimulus for the secretion of
ACTH and cortisol (Luger et al. 1987; Oleshansky et al. 1990), and trained subjects show less activation of the hypothalamic-pituitary-adrenal axis as compared with untrained subjects at matched absolute workloads (Luger et al. 1987). An increase of basal ACTH and a diminished ACTH response to ovine corticotropin-releasing hormone $(\mathrm{CRH})$ in highly trained runners has also been reported (Luger et al. 1987). In contrast, basal cortisol and ACTH levels were indistinguishable between elderly endurance athletes and sedentary controls, but cortisol responses to human CRH were significantly increased in the athlete group, and ACTH responses tended to be higher in this group (Heuser et al. 1991). These results show, that long-distance running does not lead to a decreased sensitivity for CRH on the pituitary-adrenal level.

M-CPP's effect on cortisol secretion seems to be directly related to $\mathrm{CRH}$ release from the nucleus paraventricularis, because it is suppressed in rats by pretreatment with anti-CRH rabbit serum (Calogero et al. 1990). M-CPP-induced cortisol release can also be blocked by dexamethasone and thus has been interpreted to result from increased ACTH release rather than being a primary adrenal action of m-CPP (Calogero et al. 1990). Because the nucleus paraventricularis receives neuronal inputs from various neurotransmitter systems including serotonergic pathways, the postulated downregulation of $5-\mathrm{HT}_{2 \mathrm{C}}$ receptors by intensive endurance training might occur on the level of CRH secreting neurons or "above" the nucleus paraventricularis. In the same experiment, the cortisol response of the $5-\mathrm{HT}_{1 \mathrm{~A}}$ agonist 8-OH-DPAT was not completely blocked after pretreatment with anti-CRH rabbit serum or dexamethasone. It was concluded that $5-\mathrm{HT}_{1 \mathrm{~A}}$ agonists may also act at the pituitary level to stimulate ACTH release in vivo.

In both groups, oral administration of $\mathrm{m}-\mathrm{CPP}$ in a dose of $0.4 \mathrm{mg} / \mathrm{kg}$ did not induce any significant behavioral effects. Eight out of 12 subjects did not notice any somatic or psychological symptoms during the $\mathrm{m}$-CPP challenge. Presumably, we think that this dose of $\mathrm{m}-\mathrm{CPP}$ might have been too low to detect subtle differences in serotonergic responsiveness as related to behavioral endpoints. In patients with panic disorder, the same oral dose of $\mathrm{m}$-CPP led to marked sensations of anxiety, activation, altered self-reality, depression, dysphoria, and subjective functional deficit, and more than half of the patients experienced panic attacks or acute anxiety very similar to panic attacks (Broocks et al. 1998b). At the same time, patients with panic disorder are characterized by exercise avoidance and markedly reduced aerobic fitness (Broocks et al. 1997; Martinsen et al. 1989; Miyakoda et al. 1990; Roth 1989; Roth et al. 1986; Taylor et al. 1987). Abstinence from exercise seems to be a clinically relevant component of the phobic avoidance behavior. We have recently shown that aerobic exercise leads to significant clinical improve- 
ment in patients with panic disorder (Broocks et al. 1998a). However, so far no clinical studies show that an exercise-induced remission of anxiety symptoms is associated with changes in serotonergic responsiveness. The results of the present study would support the assumption that exercise-induced downregulation of $5-\mathrm{HT}_{2 \mathrm{C}}$ receptors could play an important role in mediating the anxiolytic and antidepressive effects of exercise. This hypothesis is also in keeping with observations from animal studies that periods of acute motor activity are associated with an increased turnover of serotonin in the mediobasal hypothalamus (Broocks et al. 1991). Similar to the action of serotonin reuptake inhibitors, repeated episodes of serotonergic stimulation could induce postsynaptic changes leading to decreased sensitivity for pharmacological or physiological serotonergic inputs.

The observation that responses to ipsapirone were not altered by long-distance running is in agreement with data from animal studies. Typical behaviors in rats such as "flat body posture, forepaw treading, and hyperphagia," which can be induced by $5-\mathrm{HT}_{1 \mathrm{~A}}$ receptor agonists, were not affected by training and/or acute exercise (Chaouloff 1994). On the other hand, it has been shown that administration of the $5-\mathrm{HT}_{2 \mathrm{~A}}$ receptor blocker ketanserin prevents exercise-elicited prolactin release (de Meirleir et al. 1985). This result suggests that exercise actually triggers 5-HT release and stimulation of those $5-\mathrm{HT}_{2 \mathrm{~A}}$ receptors controlling prolactin release. A clear-cut conclusion is difficult to draw, because it is not known whether ketanserin, at the doses used, affects only $5-\mathrm{HT}_{2 \mathrm{~A}}$ receptors. Two animal studies have reported that $5-\mathrm{HT}_{2 \mathrm{~A}} / 5 \mathrm{HT}_{2 \mathrm{C}}$ receptor blockade delayed the onset of exhaustion (Bailey et al. 1993a; Bailey et al. 1993b). In contrast, $5-\mathrm{HT}_{2 \mathrm{~A}} / 5 \mathrm{HT}_{2 \mathrm{C}}$ receptor stimulation increased treadmill fatigue (Bailey et al. 1992; Bailey et al. 1993b; Davis et al. 1993). On the other hand, downregulation of these subreceptors could well contribute to the delayed onset of fatigue after regular training. Semistarvation-induced hyperactivity in rats was inhibited by $5-\mathrm{HT}_{2 \mathrm{C}}$ agonists and by alpha 2-adrenoceptor agonists (Wilckens et al. 1992). Taken together, these findings support the involvement of 5- $\mathrm{HT}_{2 \mathrm{~A}}$ and $5-\mathrm{HT}_{2 \mathrm{C}}$ receptors in the control of endurance.

Other monoaminergic neurotransmitter systems are also affected by chronic exercise. In the cerebrospinal fluid of depressed patients, concentrations of the serotonin metabolite 5-HIAA and the norepinephrine metabolite vanillylmandelic acid (VMA) were significantly higher after 4 hours of hyperactivity than in the same patients after bed rest (Post et al. 1973). Also, urinary and CSF MHPG was significantly higher during a day of increased motor activity in comparison with a day with usual ward activities in depressed patients (Beckmann et al. 1979). Semistarvation-induced hyperactivity was associated with highly significant increases in norad- renaline turnover as estimated by the main metabolite MHPG in the mediobasal hypothalamus of rats (Broocks et al. 1990). Other studies using chronic activity wheel running confirmed increased tissue concentration of 5-HT and NE at rest (Broocks et al. 1990; Broocks et al. 1991; Dishman 1997; Dunn et al. 1996). A protective effect of exercise against NE depletion in locus coeruleus cell bodies after footshock was also reported (Dishman 1997; Dunn et al. 1996). The concomitant reduction in escape latency was interpreted as consistent with an antidepressant effect. Wheel running also decreased the density of $\mathrm{GABA}_{\mathrm{A}}$ receptors in the corpus striatum while increasing open-field locomotion, consistent with an anxiolytic effect (Dishman 1997). Tyrosin hydroxylase activity has been shown to increase in the caudate of rats trained by voluntary running (Morgan et al. 1984). After a 12-week protocol of daily treadmill running, a significantly higher density of dopamine-2 receptors as labeled with $(3 \mathrm{H})$-spiperone was found in the striatum of rats (Gilliam et al. 1984; MacRae et al. 1987). In humans, an increase of $\beta$-endorphin has been observed after strenuous aerobic exercise (Krüger and Wildmann 1986; Wildmann et al. 1986), and regular training potentiated the secretion of $\beta$-endorphin (Carr et al. 1981). However, improvements of mood did not correlate with the increase of plasma $\beta$-endorphin (Farrel 1982). Naloxon antagonized the exercise-induced lowering of pain threshold but had only a very limited effect on exercise-induced psychological changes (Janal et al. 1984; Markoff et al. 1982). Also, the blood-brain barrier is relatively impermeable to pituitary $\beta$-endorphin (Kalin et al. 1985).

At baseline, plasma levels of cortisol, adrenaline, and NE were not significantly different between the two groups. However, marathon runners had significantly lower mean plasma concentrations of prolactin in comparison with the untrained controls. This could be explained by the lower number of female subjects in the marathon group, because prolactin levels are generally lower in males (Murphy et al. 1989). However, it could also be shown, that the prolactin response to $\mathrm{m}-\mathrm{CPP}$ does not differ in males and females (Murphy et al. 1989). Nevertheless, the unbalanced sex ratio is a clear methodological weakness of our study. Although female subjects did not undergo neuroendocrine testing during or 1 week before menstruation, they were not tested at corresponding stages of the menstrual cycle. This could also have had some influence on our results.

Data from the bicycle spiroergometry demonstrate that this sample of marathon runners, in fact, represented a very high fitness group. Athletes and controls performed the bicycle test with a comparable degree of exertion, which can be inferred from the fact that maximal heart rate, subjective ratings of exertion, and the respiratory exchange rate did not differ between the groups. Our results cannot answer the question of 
whether moderate exercise will also alter $5-\mathrm{HT}_{2 \mathrm{C}}$ receptor-related functions.

In conclusion, regular long-distance running seems to be associated with a significantly decreased cortisol-and possibly prolactin-response to $\mathrm{m}$-CPP. In contrast, marathon athletes and untrained controls did not differ in their behavioral, hormonal, and temperature response to the administration of ipsapirone. In a recent meta-analysis on serotonergic agonists as indices of the functional status of central serotonin neurotransmission in humans (Murphy et al. 1996), six out of 13 studies showed a divergence of neuroendocrine and psychobehavioral responses to $\mathrm{m}-\mathrm{CPP}$. As a consequence, we should be careful to interpret altered neuroendocrine response measures alone as an indicator of an ubiquitous up- or downregulation of serotonergic receptors. Nevertheless, the fact remains that the neuroendocrine response to $\mathrm{m}-\mathrm{CPP}$ seems to be affected by the degree of aerobic fitness when cortisol (and possibly prolactin) is used as endpoint measure. Exercise-induced downregulation of 5- $\mathrm{HT}_{2 \mathrm{C}}$ receptors in certain brain areas could be related to the anxiolytic and antidepressant effects of exercise.

\section{ACKNOWLEDGMENTS}

This study was supported by a public grant from the Volkswagen Foundation, Hannover, Germany.

\section{REFERENCES}

Aulakh CS, Hill JL, Murphy DL (1992): Effects of various serotonin receptor subtype-selective antagonists alone and on m-chlorophenylpiperazine-induced neuroendocrine changes in rats. J Pharmacol Exp Ther 263:588-595

Bailey SP, Davis JM, Ahlborn EN (1992): Effect of increased brain serotonergic activity on endurance performance in the rat. Acta Physiol Scand 145:75-76

Bailey SP, Davis JM, Ahlborn EN (1993a): Neuroendocrine and substrate responses to altered brain 5-HT activity during prolonged exercise to fatigue. J Appl Physiol 74:3006-3012

Bailey SP, Davis JM, Ahlborn EN (1993b): Serotonergic agonists and antagonists affect endurance performance in the rat. Int J Sports Med 14:330-333

Beckmann H, Ebert MH, Post R, Goodwin FK (1979): Effect of moderate exercise on urinary MHPG in depressed patients. Pharmacopsychiatry 12

Blomstrand E, Celsing F, Newsholme EA (1988): Changes in plasma concentrations of aromatic and branched-chain amino acids during sustained exercise in man and their possible role in fatigue. Acta Physiol Scand 133:115-121

Borg G, Noble B (1974): Perceived exertion. Exer Sports Sci Rev 2:131-153

Brewerton TD, Murphy DL, Lesem MD, Brandt HA, Jimerson DC (1992): Headache responses following m-chlo- rophenylpiperazine in bulimics and controls. Headache 32:217-222

Broocks A, Bandelow B, Pekrun G, George A, Meyer TF, Bartmann U, Hillmer-Vogel U, Rüther E (1998a): A comparison of aerobic exercise, clomipramine, and placebo in the treatment of panic disorder. Am J Psychiat 155:603-609

Broocks A, George A, Jestrabek C, Optiz M, Bartmann U, Gleiter CH, Meineke I, Roed IS, Bandelow B, Hajak G, Rüther E (1998b): Increased psychobehavioral sensitivity for both m-CPP and ipsapirone in patients with panic disorder. Psychiat Res (submitted)

Broocks A, Liu J, Pirke KM (1990): Semistarvation-induced hyperactivity compensates for decreased norepinephrine and dopamine turnover in the mediobasal hypothalamus of the rat. J Neural Transm 79:113-124

Broocks A, Meyer TF, Bandelow B, George A, Bartmann U, Rüther E, Hillmer-Vogel U (1997): Exercise avoidance and impaiared endurance capacity in patients with panic disorder. Neuropsychobiology 36:182-187

Broocks A, Schweiger U, Pirke KM (1989): The influence of hyperactivity on the metabolism of central monoaminergic neurotransmitters and reproductive function in the semistarved rat. In Pirke KM, Wuttke W, Schweiger U, (eds), The Menstrual Cycle and its Disorders-Influences of Nutrition, Exercise, and Neurotransmitters. Berlin, Heidelberg, Springer Verlag pp 89-96

Broocks A, Schweiger U, Pirke KM (1991): The influence of semistarvation-induced hyperactivity on hypothalamic serotonin metabolism. Physiol Behav 50:385-388

Calogero AE, Bagdy G, Moncada ML, D'Agata R (1993): Effect of selective serotonin agonists on basal, corticotrophin-releasing hormone- and vasopressin-induced ACTH release in vitro from rat pituitary cells. J Endocrinol 136:381-387

Calogero AE, Bagdy G, Szemeredi K, Tartaglia ME, Gold PW, Chrousos GP (1990): Mechanisms of serotonin receptor agonist-induced activation of the hypothalamic-pituitary-adrenal axis in the rat. Endocrinology 126:1888-1894

Carr DB, Bullen BA, Skrinar GS, Arnold MA, Rosenblatt M, Beitins IZ, Martin JB, McArthur JW (1981): Physical conditioning facilitates the exercise-induced secretion of beta-endorphin and beta-lipitropin in women. New Engl J Med 3:560-563

Chaouloff F (1994): Influence of physical exercise on 5-HT1A receptor- and anxiety-related behaviors. Neurosci Lett 176:226-230

Chaouloff F (1997): Effects of acute physical exercise on central serotonergic systems. Med Sci Sports Exerc 29:58-62

Chaouloff F, Laude D, Elghozi JL (1989): Physical exercise: Evidence for differential consequences of tryptophan on 5-HT synthesis and metabolism in central serotonergic cell bodies and terminal. J Neural Transm 78:121-130

Chaouloff F, Laude D, Guezennec Y, Elghozi JL (1986): Motor activity increases tryptophan, 5-hydroxyindoleacetic acid, and homovanillic acid in ventricular cerebrospinal fluid of the conscious rat. J Neurochem 46:1313-1316

Davis C, Brewer H, Ratusny D (1993): Behavioral frequency and psychological commitment: Necessary concepts in 
the study of excessive exercising. J Behavioral Med 16:611-628

Davis JM, Bailey SP, Woods JA, Galiano FJ, Hamilton MT, Bartoli WP (1992): Effects of carbohydrate feedings on plasma-free tryptophan and branched-chain amino acids during prolonged cycling. Eur J Appl Physiol 65:513-579

de Coverley Veale DMW (1987): Exercise and mental health. Acta Psychiat Scand 76:113-120

de Meirleir KL, L'Hermite-Baleriaux M, L'Hermite M, Rost R, Hollmann W (1985): Evidence for serotoninergic control of exercise-induced prolactin secretion. Horm Metabol Res 17:380-381

De Vry J, Glaser T, Schuurmann T, Schreiber R, Traber J (1991): $5-\mathrm{HT}_{1 \mathrm{~A}}$ receptors in anxiety. In Briley $\mathrm{M}$ (ed), New Concepts in Anxiety. London, McMillan

Dillon DJ, Gorman JM, Liebowitz MR, Fyer AJ, Klein DF (1987): Measurement of lactate-induced panic and anxiety. Psychiat Res 20:97-105

Dishman RK (1997): Brain monoamines, exercise, and behavioral stress: Animal models. Med Sci Sports Exerc 29:63-74

Doyne EJ, Ossip-Klein DJ, Bowman ED, Osborn KM, McDougall-Wilson IB, Neimeyer RA (1987): Running versus weightlifting in the treatment of depression. J Consult Clin Psychol 55:748-754

Dunn AL, Reigle TG, Youngstedt SG, Armstrong RB, Dishman RK (1996): Brain norepinephrine and metabolites after treadmill training and wheel running in rats. Med Sci Sports Exerc 28:204-209

Farmer ME, Locke BZ, Moscicki EK, Dannenberg AL, Larson DB, Radloff LS (1988): Physical activity and depressive symptoms: The NHANES I epidemiological follow-up study. Am J Epidemiol 128:1340-1351

Farrel PA (1982): Increases in plasma $\beta$-endorphin/ $\beta$-lipotropin immunoreactivity after treadmill running in humans. J Appl Physiol 52:1245-1252

Fernstrom JD, Wurtman RJ (1971): Brain serotonin content: Physiological dependence on plasma tryptophan levels. Science 173:149-152

Fischer HG, Hollmann W, De Meirleir K (1991): Exercise changes in plasma tryptophan fractions and relationship with prolactin. Int J Sports Med 12:487-489

Gilliam PE, Spirduso WW, Martin TP, Walters TJ, Wilcox RE, Farrar RP (1984): The effects of exercise training on $[3 \mathrm{H}]$-spiperone binding in rat striatum. Pharmacol Biochem Behav 20:863-867

Greenhouse SW, Geisser S (1959): On methods in the analysis of profile data. Psychometrika 32:95-112

Greist JH, Klein MH, Eischens RR, Faris J, Gurman AS, Morgan WP (1979): Running as treatment for depression. Compr Psychiat 20:41-54

Heuser IJ, Wark HJ, Keul J, Holsboer F (1991): Hypothalamic-pituitary-adrenal axis function in elderly endurance athletes. J Clin Endocrinol Metab 73:485-488

Hollander E, DeCaria C, Nitescu A (1992): Effects of chronic fluoxetine treatment on behavioral and neuroendocrine responses to $\mathrm{m}-\mathrm{CPP}$ in obsessive-compulsive disorder. Psychiat Res 36:1-17

Hughes JR (1984): Psychological effects of habitual aerobic exercise: A critical review. Preventive Med 13:66-78
Janal MN, Colt EWD, Clark WC, Glusman M (1984): Pain sensitivity, mood, and plasma endocrine levels in man following long-distance running: Effects of naloxone. Pain 19:13-25

Kahn RS, Trestman R, Lawlor BA, Gabriel S, Davidson M, Siever L (1994): Effects of ipsapirone in healthy subjects: A dose-response study. Psychopharmacol Berl 114:155160

Kahn RS, Wetzler S (1991): m-Chlorophenylpiperazine as a probe of serotonergic function. Biol Psychiat 30:11391166

Kalin NH, Carnes M, Barksdale CM, Shelton SE, Stewart RD, Risch SC (1985): Effects of acute behavioral stress on plasma and cerebrospinal fluid ACTH and beta-endorphin in rhesus monkeys. Neuroendocrinology 40:97-101

Kennett GA, Whitton P, Shah K, Curzon G (1989): Anxiogenic-like effects of $\mathrm{MCPP}$ and TFMPP in animal models are opposed by 5-HT1C receptor antagonists. Eur J Pharmacol 164:445-454

Krüger A, Wildmann J (1986): Anstieg des $\beta$-Endorphinspiegels bei Wiederholungsbelastungen. D Zeitschr Sportmed 37:245-250

Lennox SS, Bedell JR, Stone AA (1990): The effect of exercise on normal mood. J Psychosom Res 34:629-636

Lesch KP, Poten B, Sohnie K, Schulte HM (1990): Pharmacology of the hypothermic response to $5-\mathrm{HT}_{1 \mathrm{~A}}$ receptor activation in humans. Eur J Clin Pharmacol 39:17-19

Lesch KP, Rupprecht R, Poten B, Muller U, Sohnle K, Fritze J, Schulte HM (1989): Endocrine responses to 5-hydroxytryptamine-1A receptor activation by ipsapirone in humans. Biol Psychiat 26:203-205

Luger A, Deuster PA, Kyle SB, Gallucci WT, Montgomery LC, Gold PW, Leriaux DL, Chrousos GP (1987): Acute hypothalamic-pituitary-adrenal responses to the stress of treadmill exercise. N Engl J Med 316:1309-1315

MacMahon JR (1990): The psychological benefits of exercise and the treatment of delinquent adolescents. Sports Med 9:344-351

MacRae PG, Spirduso WW, Cartee GD, Farrar RP, Wilcox RE (1987): Endurance training effects on striatal D2 dopamine receptor binding and striatal dopamine metabolite levels. Neurosci Lett 79:138-144

Markoff RA, Ryan P, Young T (1982): Endorphins and mood changes in long-distance running. Med Sci Sports Exerc 14:11-15

Martinsen EW, Medhus A, Sandvik L (1985): Effects of aerobic exercise on depression: A controlled study. Brit Med J 291:109

Martinsen EW, Strand J, Paulsson G, Kaggestad J (1989): Physical fitness level in patients with anxiety and depressive disorder. Int J Sports Med 10:58-61

Mazzola-Pomietto P, Aulakh CS, Wozniak KM, Hill JL, Murphy DL (1995): Evidence that 1-(2,5-dimethoxy-4iodophenyl)-2-aminopropane (DOI)-induced hyperthermia in rats is mediated by stimulation of $5-\mathrm{HT}_{2 \mathrm{~A}}$ receptors. Psychopharmacology Berl 117:193-199

McCann IL, Holmes DS (1984): Influence of aerobic exercise on depression. J Personal Soc Psych 46:1142-1147

Miyakoda H, Kitamura H, Kinuguwa T, Saito M, Kotake H, Mashiba H (1990): Cardiac neurosis: Exercise tolerance 
and the role of sympathetic activity. Japan J Med 29:493-499

Morgan ME, Yamamoto BK, Freed CR (1984): Unilateral activation of caudate tyrosine hydroxylase during voluntary circling behavior. J Neurochem 43:737-741

Murphy DL, Aulakh CS, Mazzola-Pomietto P, Briggs NC (1996): Neuroendocrine responses to serotonergic agonists as indices of the functional status fo central serotonin neurotransmission in humans. Behav Brain Res 73:209-214

Murphy DL, Lesch KP, Aulakh CS, Pigott TA (1991): Serotonin-selective arylpiperazines with neuroendocrine, behavioral, temperature, and cardiovascular effects in humans. Pharmacol Rev 43:527-552

Murphy DL, Mueller EA, Hill JL, Tolliver TJ, Jacobsen FM (1989): Comparative anxiogenic, neuroendocrine, and other physiologic effects of $\mathrm{m}$-chlorophenylpiperazine given intravenously or orally to healthy volunteers. Psychopharmacol Berl 98:275-282

Oleshansky MA, Zoltick JM, Herman RH, Mougey EH, Meyerhoff JL (1990): The influence of fitness on neuroendocrine responses to exhaustive treadmill exercise. Eur J Appl Physiol 59:405-410

Pappas GP, Golin S, Meyer DL (1990): Reducing symptoms of depression with exercise. Psychosom 31:112-113

Peroutka SJ (1985): Selective interaction of novel anxiolytics with 5-hydroxytryptamine1A receptors. Biol Psychiat 20:971-979

Pigott TA, Hill JL, Grady TA, L'Heureux F, Bernstein S, Rubenstein CS, Murphy DL (1993): A comparison of the behavioral effects of oral versus intravenous $\mathrm{mCPP}$ administration in OCD patients and the effect of metergoline prior to i.v. mCPP. Biol Psychiat 33:3-14

Pirke KM, Schweiger U, Lemmel W, Krieg JC, Berger M (1985): The influence of dieting on the menstrual cycle of healthy young women. J Clin Endocrinol Metab 60:1174-1179

Post RM, Kotin J, Goodwin FK, Gordon EK (1973): Psychomotor activity and cerebrospinal fluid metabolites in affective illness. Am J Psychiat 130:67-72

Przegalinski E, Budziszewska B, Warchol Kania A, Blaszczynska E (1989): Stimulation of corticosterone secretion by the selective $5-\mathrm{HT}_{1 \mathrm{~A}}$ receptor agonist 8-hydroxy-2- (di-n-propylamino)tetralin (8-OH-DPAT) in the rat. Pharmacol Biochem Behav 33:329-334

Quested DJ, Sargent PA, Cowen PJ (1997): SSRI treatment decreases prolactin and hyperthermic responses to mCPP. Psychopharmacology 133:305-308

Roth DL (1989): Acute emotional and psychophysiological effects of aerobic exercise. Psychophysiology 26:593-602

Roth WT, Telch MJ, Taylor CB, Sachitano JA, Gallen CC, Kopell ML, McClenahen KL, Agras WS, Pfefferbaum A (1986): Autonomic characteristics of agoraphobia with panic attacks. Biol Psychiat 21:1133-1154

SAS (1989): SAS User's Guides. SAS Institute Inc., Cary, North Carolina

Seibyl JP, Krystal JH, Price LH (1991): Effects of ritanserin on the behavioral, neuroendocrine, and cardiovascular responses to $\mathrm{m}-\mathrm{CPP}$ in human healthy subjects. Psychiat Res 38:227-236

Sexton H, Maere A, Dahl NH (1989): Exercise intensity and reduction in neurotic symptoms-A controlled followup study. Acta Psychiat Scand 80:231-235

Sothman MS, Hart BA, Horn TS (1992): Sympathetic nervous system and behavioral responses to stress following exercise training. Physiol \& Behav 51:1097-1103

Taylor CB, King R, Ehlers A, Margraf J, Clark D, Hayward C, Roth WT, Agras S (1987): Treadmill exercise test and ambulatory measures in panic attacks. Am J Cardiol 60:48J-52J

Wilckens T, Schweiger U, Pirke KM (1992): Activation of alpha 2-adrenoceptors suppresses excessive wheel running in the semistarvation-induced hyperactive rat. Pharmacol Biochem Behav 43:733-738

Wildmann J, Krüger A, Schmole M, Niemann J, Matthaei H (1986): increase of beta-endorphin-like immunoreactivity correlates with the change in feeling of pleasantness after running. Life Sci 38:997-1003

Wurtman RJ, Fernstrom JD (1976): Control of brain neurotransmitter synthesis by precursor availability and nutritional state. Biochem Pharmacol 25:1691-1696

Zohar J, Insel TR, Zohar Kadouch RC, Hill JL, Murphy DL (1988): Serotonergic responsivity in obsessive-compulsive disorder. Effects of chronic clomipramine treatment. Arch Gen Psychiat 45:167-172 